\title{
Prorenin anno 2008
}

\author{
A. H. Jan Danser • Wendy W. Batenburg • \\ Joep H. M. van Esch • Manne Krop
}

Received: 9 January 2008 /Revised: 31 January 2008 /Accepted: 1 February 2008 / Published online: 6 March 2008

(C) The Author(s) 2008

\begin{abstract}
For many years, prorenin has been considered to be nothing more than the inactive precursor of renin. Yet, its elevated levels in diabetic subjects with microvascular complications and its extrarenal production at various sites in the body suggest otherwise. This review discusses the origin, regulation, and enzymatic activity of prorenin, its role during renin inhibition, and the angiotensin-dependent and angiotensin-independent consequences of its binding to the recently discovered (pro)renin receptor. The review ends with the concept that prorenin rather than renin determines tissue angiotensin generation.
\end{abstract}

Keywords (Pro)renin receptor - Renin ·

Renin angiotensin system $\cdot$ Diabetes $\cdot$ Signaling .

Tissue angiotensin $\cdot$ Renin inhibitor $\cdot$ Receptor

\section{Introduction}

Despite nearly 40 years of research on prorenin, the renin precursor is still the least well-understood component of the renin-angiotensin system (RAS). Initially, it was thought to have no function at all. Yet, it circulates in human plasma in excess to renin, sometimes at concentrations that are 100 times higher, and in plasma of anephric subjects, prorenin,

\footnotetext{
A. H. J. Danser $(\bowtie) \cdot$ W. W. Batenburg • J. H. M. van Esch •

M. Krop

Division of Vascular Pharmacology and Metabolism,

Department of Internal Medicine, Erasmus MC,

room EE1418b, Dr. Molewaterplein 50,

3015 GE Rotterdam, The Netherlands

e-mail: a.danser@erasmusmc.nl
}

but not renin, is still present $[1,2]$. This suggests that prorenin, in contrast with renin, is also of extrarenal origin. Prorenin is particularly elevated in diabetic subjects with microvascular complications [3]. Moreover, the renal vasodilator response to captopril in diabetic subjects correlated better with plasma prorenin rather than with plasma renin [4]. Thus, (circulating) prorenin may have a function after all. Possibly, it is prorenin (and not renin) which is responsible for tissue angiotensin generation. Obviously, this would require local prorenin-renin conversion, for which no evidence exists [5]. In support of this concept, however, transgenic rodents with (inducible) prorenin expression in the liver display increased cardiac angiotensin (Ang) I levels, cardiac hypertrophy, and/or vascular damage $[6,7]$.

\section{Origin and regulation of prorenin}

The juxtaglomerular epithelioid cells, located in the walls of renal afferent arterioles, are the main source of renin in the body. Renin is synthesized as preprorenin. Preprorenin is converted to prorenin upon insertion into the endoplasmatic reticulum. The majority $(75 \%)$ of prorenin is secreted constitutively, while the remainder is targeted to dense core secretory granules. In these granules, an acidic $\mathrm{pH}$ is created to optimize the activity of the proteases (cathepsin $\mathrm{B}$, prohormone convertases) that cleave off the prosegment to yield renin. Prorenin and renin levels are highly correlated but do not alter in parallel under all circumstances [1]. Acute stimuli of renin will not affect prorenin levels, whereas chronic stimuli (like a decrease in Ang II) increase both renin and prorenin. This suggests that renin is stored as active enzyme and is released immediately upon 
stimulation of the juxtaglomerular apparatus. Prorenin is released constitutively, and no acute responses occur. Chronic stimulation causes more prorenin to be converted to renin, leading to an increased renin/prorenin ratio in plasma. However, some exceptions to this rule exist. A well-known example is, as mentioned above, diabetes mellitus complicated by retinopathy and nephropathy [3]. Pregnant women also have high plasma prorenin levels, derived from the ovaries [8]. The function of this prorenin is unknown, as is the function of prorenin in amniotic fluid, in which prorenin was discovered. The reproductive organs, together with the adrenal, eye, and submandibular gland, are sites of extrarenal renin gene expression [9]. For reasons that are not understood, these tissues predominantly, if not exclusively, synthesize and release prorenin.

\section{Enzymatic activity of prorenin?}

A 43-amino-acid N-terminal propeptide explains the absence of enzymatic activity of prorenin. This propeptide covers the enzymatic cleft and obstructs access of angiotensinogen to the active site of renin. Prorenin can be activated in two ways: proteolytic or nonproteolytic [10]. Proteolytic activation is irreversible: it involves actual removal of the propeptide. Nonproteolytic activation of prorenin is reversible. It can best be imagined as an unfolding of the propeptide from the enzymatic cleft. Nonproteolytic activation can be induced by exposure to low $\mathrm{pH}(\mathrm{pH}=3.3)$ or cold $\left(4^{\circ} \mathrm{C}\right)[10]$. Nonproteolytically activated prorenin is enzymatically active and can be recognized by monoclonal antibodies that are specific for the active site. Kinetic studies of the nonproteolytic activation process have indicated that an equilibrium exists between the closed (inactive) and open (active) forms of prorenin. The inactivation step is highly temperature dependent and occurs very rapidly at neutral $\mathrm{pH}$ and $37^{\circ} \mathrm{C}$. Consequently, under physiological conditions, $<2 \%$ of prorenin is in the open and active form, i.e., displays enzymatic activity, and $>98 \%$ is closed and inactive.

\section{Prorenin receptor(s)?}

The beneficial effects of RAS blockers are due, at least in part, to blockade of the generation or action of Ang II at tissue sites [11]. In tissues that are believed not to express the renin gene, like the heart and vascular wall, such angiotensin generation depends on renin/prorenin taken up from the circulation. Simple diffusion cannot explain the relatively high renin levels in these organs, and thus a receptor-mediated mechanism may exist. Two candidates currently have been proposed: the mannose 6-phosphate/ insulin-like growth factor II receptor (M6P/IGF2R) [12-14] and the (pro)renin receptor [15]. The M6P/IGF2R nonselectively binds M6P-containing proteins like renin and prorenin. However, such binding did not result in angiotensin generation, and it is now believed that the M6P/ IGF2R is a clearance receptor for renin/prorenin [16]. This leaves the (pro)renin receptor as the most promising candidate for tissue uptake of circulating renin/prorenin. This receptor, a 350-amino-acid protein with a single transmembrane domain, binds prorenin with higher affinity than renin [17] and, unlike the M6P/IGF2R, does not internalize these proteins. Interestingly, binding to the receptor allowed prorenin to become catalytically active without proteolytic cleavage of the prosegment $[15,17]$. Apparently, therefore, binding induces a conformational change in the prorenin molecule, similar to the change occurring after exposure to cold or low $\mathrm{pH}$.

\section{Angiotensin-independent effects of prorenin?}

After the discovery of the receptor, (pro)renin receptor antagonists were designed based on the idea that the prosegment
Fig. 1 Model depicting prorenin activation by the (pro)renin receptor $(\mathrm{P}) \mathrm{RR}$, allowing prorenin to generate angiotensin I from angiotensinogen. In addition, prorenin binding to the receptor results in effects (intracellular signaling) that are independent of angiotensin generation. HRP is assumed to block both prorenin activation and the direct prorenininduced effects (see text for further explanation)
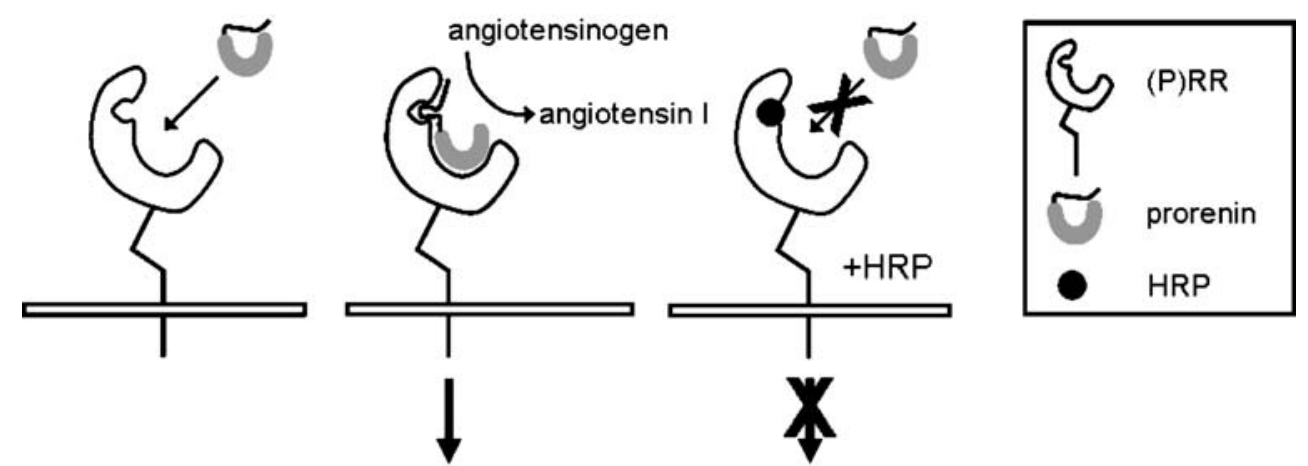

angiotensin-independent effects 
contains a 'handle region' which binds to the receptor [18]. These (peptidic) antagonists (also known as 'handle region peptides', HRP) mimic the handle region and thus may bind to the receptor instead of prorenin. In support of this concept, HRP infusion normalized the elevated renal angiotensin content in diabetic rats [18] and simultaneously prevented the development of diabetic nephropathy.

Surprisingly, identical effects occurred in diabetic angiotensin II type 1A receptor-deficient mice [19]. Since such mice no longer display the normal (constrictor) response to Ang II [20], the effect of the (pro)renin receptor antagonist in these mice cannot be due to suppression of local angiotensin generation. Thus, prorenin may also exert direct angiotensin-independent effects, possibly via the above described (pro)renin receptor (Fig. 1). Indeed, prorenin (and renin) induced p42/p44 mitogen-activated protein kinase (MAPK) activation and transforming growth factor- $\beta 1$ release in mesangial cells $[15,21]$, and these effects did not occur following deletion of the receptor with siRNA [21]. Moreover, in cardiomyocytes, prorenin concentration dependently activated p38 MAPK and phosphorylated heat shock protein 27 [22].

Overexpression of the human (pro)renin receptor in rats resulted in elevated blood pressure, increased plasma aldosterone, and/or glomerulosclerosis [23, 24]. Since such overexpression was not accompanied by changes in renin or Ang II, angiotensin-independent effects of the receptor may underlie this phenotype. HRP prevented the development of glomerulosclerosis in (pro)renin receptor transgenic rats [25]. Yet, transgenic rats with inducible hepatic prorenin expression (resulting in a $>200$-fold rise in plasma prorenin) did not develop glomerulosclerosis [26], although such animals did develop hypertension. Moreover, HRP blocked neither prorenin binding to cells overexpressing the human (pro)renin receptor [17] nor prorenin-induced signaling in U937 monocytes [27]. Thus, it is uncertain to what degree the beneficial in vivo effects of HRP are solely due to prorenin blockade. Such effects are unlikely to involve renin, since HRP will not block renin-(pro)renin receptor interaction.

\section{Prorenin and renin inhibition}

Prorenin levels will rise during renin inhibition, as they do during any type of RAS blockade. Renin inhibitors affect the equilibrium between the open and closed forms of prorenin, because such drugs (due to their high affinity for the active site) prevent inactivation [10]. Therefore, renin inhibitors, like low $\mathrm{pH}$, cold, and the (pro)renin receptor, are capable of nonproteolytically 'activating' prorenin although, of course, due to the presence of the renin inhibitor, this open prorenin cannot display enzymatic activity. Open prorenin will however be recognized by the active sitedirected antibodies applied in renin immunoradiometric assays, thus leading to an overestimation of the renin rise during renin inhibition [28].

Theoretically, the elevated (pro)renin levels during renin inhibition might result in (pro)renin receptor activation. In vitro studies suggest that renin inhibitors do not interfere with this process. The consequence of such overstimulation is unknown. However, since such a rise also occurs during other types of RAS blockade, its detrimental effects, if present, should have been known by now. A possible explanation comes from the work of Schefe et al. [29], who showed that, on activation of the receptor, the transcription factor promyelocytic zinc finger is translocated to the nucleus and represses transcription of the (pro)renin receptor itself, thus creating a short negative feedback loop. In other words, high (pro)renin levels, as occurring during RAS blockade, will suppress (pro)renin receptor expression, thereby preventing excessive receptor activation. Furthermore, the members of a family with a mutated renin allele, resulting in high plasma prorenin levels, were phenotypically normal [30].

\section{Conclusion}

After many years, it now seems that a function for prorenin has been found. The 'inactive' renin precursor gains Ang I-generating activity by binding to a receptor, without undergoing proteolytic cleavage. This mechanism explains how prorenin might contribute to tissue angiotensin generation, even when no prorenin-renin conversion occurs outside the kidney. Renin inhibitors will bind to such open activated prorenin, to the same degree as they bind to renin, and may thus be the ideal tools to block tissue angiotensin generation. In vitro studies suggest that prorenin also acts as an agonist of the (pro)renin receptor, inducing intracellular signaling pathways in an angiotensin-independent manner. However, given the contradictory data obtained with the (pro)renin receptor blocker HRP, more work is needed to verify the in vivo importance of such prorenininduced (pro)renin receptor activation.

Open Access This article is distributed under the terms of the Creative Commons Attribution Noncommercial License which permits any noncommercial use, distribution, and reproduction in any medium, provided the original author(s) and source are credited.

\section{References}

1. Danser AHJ, Derkx FHM, Schalekamp MADH, Hense HW, Riegger GAJ, Schunkert H (1998) Determinants of interindividual variation of renin and prorenin concentrations: evidence for a 
sexual dimorphism of (pro)renin levels in humans. J Hypertens $16: 853$

2. Krop M, de Bruyn JHB, Derkx FHM, Danser AHJ (2008) Renin and prorenin disappearance in humans post-nephrectomy: evidence for binding? Front Biosci 13:3931

3. Luetscher JA, Kraemer FB, Wilson DM, Schwartz HC, BryerAsh M (1985) Increased plasma inactive renin in diabetes mellitus. A marker of microvascular complications. N Engl J Med 312:1412

4. Stankovic AR, Fisher NDL, Hollenberg NK (2006) Prorenin and angiotensin-dependent renal vasoconstriction in type 1 and type 2 diabetes. J Am Soc Nephrol 17:3293

5. Lenz T, Sealey JE, Maack T, James GD, Heinrikson RL, Marion D, Laragh JH (1991) Half-life, hemodynamic, renal, and hormonal effects of prorenin in cynomolgus monkeys. Am J Physiol 260:R804

6. Prescott G, Silversides DW, Reudelhuber TL (2002) Tissue activity of circulating prorenin. Am J Hypertens 15:280

7. Véniant M, Ménard J, Bruneval P, Morley S, Gonzales MF, Mullins JJ (1996) Vascular damage without hypertension in transgenic rats expressing prorenin exclusively in the liver. J Clin Invest 98:1966

8. Derkx FHM, Alberda AT, de Jong FH, Zeilmaker FH, Makovitz JW, Schalekamp MADH (1987) Source of plasma prorenin in early and late pregnancy: observations in a patient with primary ovarian failure. J Clin Endocrinol Metab 65:349

9. Krop M, Danser AHJ (2008) Circulating versus tissue reninangiotensin system: on the origin of (pro)renin. Curr Hyp Rep (in press)

10. Danser AHJ, Deinum J (2005) Renin, prorenin and the putative (pro)renin receptor. Hypertension 46:1069

11. Danser AHJ (2003) Local renin-angiotensin systems: the unanswered questions. Int J Biochem Cell Biol 35:759

12. van Kesteren CAM, Danser AHJ, Derkx FHM, Dekkers DHW, Lamers JMJ, Saxena PR, Schalekamp MADH (1997) Mannose 6-phosphate receptor-mediated internalization and activation of prorenin by cardiac cells. Hypertension 30:1389

13. Saris JJ, Derkx FHM, de Bruin RJA, Dekkers DHW, Lamers JMJ, Saxena PR, Schalekamp MADH, Danser AHJ (2001) Highaffinity prorenin binding to cardiac man-6-P/IGF-II receptors precedes proteolytic activation to renin. Am J Physiol 280:H1706

14. van den Eijnden MMED, Saris JJ, de Bruin RJA, de Wit E, Sluiter W, Reudelhuber TL, Schalekamp MADH, Derkx FHM, Danser AHJ (2001) Prorenin accumulation and activation in human endothelial cells. Importance of mannose 6-phosphate receptors. Arterioscler Thromb Vasc Biol 21:911

15. Nguyen G, Delarue F, Burcklé C, Bouzhir L, Giller T, Sraer J-D (2002) Pivotal role of the renin/prorenin receptor in angiotensin II production and cellular responses to renin. J Clin Invest 109:1417

16. Saris JJ, van den Eijnden MMED, Lamers JMJ, Saxena PR, Schalekamp MADH, Danser AHJ (2002) Prorenin-induced myocyte proliferation: no role for intracellular angiotensin II. Hypertension 39:573

17. Batenburg WW, Krop M, Garrelds IM, de Vries R, de Bruin RJA, Burcklé C, Müller DN, Bader M, Nguyen G, Danser AHJ (2007) Prorenin is the endogenous agonist of the (pro)renin receptor. Binding kinetics of renin and prorenin in rat vascular smooth muscle cells overexpressing the human (pro)renin receptor. J Hypertens 25:2441
18. Ichihara A, Hayashi M, Kaneshiro Y, Suzuki F, Nakagawa T, Tada Y, Koura Y, Nishiyama A, Okada H, Uddin MN, Nabi AH, Ishida Y, Inagami T, Saruta T (2004) Inhibition of diabetic nephropathy by a decoy peptide corresponding to the "handle" region for nonproteolytic activation of prorenin. J Clin Invest 114:1128

19. Ichihara A, Suzuki F, Nakagawa T, Kaneshiro Y, Takemitsu T, Sakoda M, Nabi AH, Nishiyama A, Sugaya T, Hayashi M, Inagami T (2006) Prorenin receptor blockade inhibits development of glomerulosclerosis in diabetic angiotensin II type 1a receptor-deficient mice. J Am Soc Nephrol 17:1950

20. van Esch JHM, Schuijt MP, Sayed J, Choudry Y, Walther T, Danser AHJ (2006) AT2 receptor-mediated vasodilation in the mouse heart depends on AT1A receptor activation. Br J Pharmacol 148:452

21. Huang Y, Wongamorntham S, Kasting J, McQuillan D, Owens RT, Yu L, Noble NA, Border W (2006) Renin increases mesangial cell transforming growth factor-beta1 and matrix proteins through receptor-mediated, angiotensin II-independent mechanisms. Kidney Int 69:105

22. Saris JJ, 't Hoen PAC, Garrelds IM, Dekkers DHW, den Dunnen JT, Lamers JMJ, Danser AHJ (2006) Prorenin induces intracellular signalling in cardiomyocytes independently of angiotensin II. Hypertension 48:564

23. Burcklé CA, Danser AHJ, Müller DN, Garrelds IM, Gasc JM, Popova E, Plehm R, Peters J, Bader M, Nguyen G (2006) Elevated blood pressure and heart rate in human renin receptor transgenic rats. Hypertension 47:552

24. Kaneshiro Y, Ichihara A, Takemitsu T, Sakoda M, Suzuki F, Nakagawa T, Hayashi M, Inagami T (2006) Increased expression of cyclooxygenase-2 in the renal cortex of human prorenin receptor gene-transgenic rats. Kidney Int 70:641

25. Kaneshiro Y, Ichihara A, Sakoda M, Takemitsu T, Nabi AHMN, Uddin MN, Nakagawa T, Nishiyama A, Suzuki F, Inagami T, Itoh H (2007) Slowly progressive, angiotensin II-independent glomerulosclerosis in human (pro)renin receptor-transgenic rats. J Am Soc Nephrol 18:1789

26. Peters B, Grisk O, Becher B, Wanka H, Kuttler B, Ludemann J, Lorenz G, Rettig R, Mullins JJ, Peters J (2008) Dose-dependent titration of prorenin and blood pressure in cyplalren-2 transgenic rats: absence of prorenin-induced glomerulosclerosis. J Hypertens 26:102

27. Feldt S, Batenburg WW, Mazak I, Maschke U, Wellner M, Kvakan H, Dechend R, Fiebeler A, Burcklé C, Contrepas A, Dannser AHJ, Bader M, Nguyen G, Luft FC, Muller DN (2008) Prorenin and renin-induced ERK $1 / 2$ activation in monocytes is not blocked by aliskiren or the handle-region peptide. Hypertension (in press)

28. Ménard J, Guyene TT, Peyrard S, Azizi M (2006) Conformational changes in prorenin during renin inhibition in vitro and in vivo. J Hypertens 24:529

29. Schefe JH, Menk M, Reinemund J, Effertz K, Hobbs RM, Pandolfi PP, Ruiz P, Unger T, Funke-Kaiser H (2006) A novel signal transduction cascade involving direct physical interaction of the renin/prorenin receptor with the transcription factor promyelocytic zinc finger protein. Circ Res 99:1355

30. Villard E, Lalau JD, van Hooft IS, Derkx FHM, Houot AM, Pinet F, Corvol P, Soubrier F (1994) A mutant renin gene in familial elevation of prorenin. J Biol Chem 269:30307 